\title{
Drug Resistance of Mycobacterium Tuberculosis in Korea
}

\author{
Sang Jae Kim, Sc.D. and Young Pyo Hong, M.D. \\ Korean Institute of Tuberculosis, Korean National Tuberculosis Association, Seoul, Korea \\ Yong Chul Han, M.D. \\ Department of Internal Medicine, Seoul National University, College of Medicine, Seoul, Korea \\ Sung Jin Kim, M.D. \\ Department of Internal Medicine, Wallace Memorial Baptist Hospital, Pusan, Korea
}

= 국문초록 $=$

\section{한국인 결핵환자로 부터 분리된 인형결핵균의 약제내성}

대한결핵협회 결핵연구원

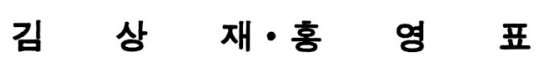

서울대학교 의 과대학 내과학교실

한 용 철

Wallace 기념 침례병원 내과

김 성 진

전국 결핵실태 조사에서 발견된 결핵환자와 보건소 또는 일반 병의원에서 진단된 환자 중 결핵치료 경험이 없는 환자로 부터 분리배양된 인형결핵균으로 각종 항결핵제에 대한 감수성검사를 실시한 결 과 각약제에 대한 내성률은 그약제의 사용정도에 비례하고 그리고 전체 내성률은 결핵 치료효율과 역 비례한다는 사실을 알 수 있었다.

1965 년에 실시한 1차 결핵 실태조사에서 분리된 결핵균은 $38.0 \%$ 가 하나 또는 그이상의 약제에 대 해 내성이었고 그후 다제 (多劑) 내성은 증가했지만 전체 내성률은 큰 변화가 없었다. 그러나 1980년에 내성률이 $48.0 \%$ 로 크게 중가했다. 이는 1980 년 초에 평가한 보건소 결핵 치료효율이 $47 \%$ 를 넘지 못 한 것으로 보아 그동안 치료실패자의 누적이 있었기 때문인 것으로 추정된다. 그후 결핵치료 효율이 계속 중가하면서 내성률은 크게 감소하여 1985 년에는 $30.8 \%, 1990$ 년에는 $25.3 \%$ 로 밝혀졌다. 초희 내성률도 비슷한 변화추세를 보여주어 1965 년에는 $26.2 \%, 1970$ 년에 $23.9 \%, 1975$ 년에 $20.1 \%$, 1980 년에 $30.6 \%, 1985$ 년에 $17.4 \%$ 그리고 1990 년에 $15.0 \%$ 로 밝혀졌다. 보건소 또는 병의원 환자의 초회내성률도 이와 크게 다르지 않았다. 그리고 초회내성이 농촌 보다는 도시환자 가운데서 더 많았 고 나이가 많은 환자 보다 적은 환자에서 더 많았다.

이상의 결과로 보아 약제내성률 조사가 결핵환자 치료관리의 효율성을 추구 평가하는데 매우 유용 하다는 사실을 알 수 있다. 


\section{INTRODUCTION}

Drug resistance of Mycobacterium tuberculosis develops by the selective growth of resistant mutants evolved in a wild population when exposed to a sufficient amount of drug that can inhibit growth of sensitive organisms ${ }^{1 \sim 3)}$. Drug resistant mutants eveolve most likely by the chromosomal mutation that leads to escape or to be prevented from drug-induced metabolic damage probably by a decreased permeability of the cell wall or membrane against drug, by a decreased affinity of drug binding sites, by inactivation of drug or by a loss of enzyme that activates drug ${ }^{1,2,4,5)}$.

The major concerns over durg resistance were a fear of spread of drug-resistant organisms and ineffectiveness of chemotherapy of the patients infected with them. In view of the results so far observed, however, there is no clear evidence of ever-increase of the primary drug resistance (PR) in most countries although relatively high prevalences were often reported from the developing countries ${ }^{2,4,6}$. And it has also been shown in several reports that the patients with initial drug resistance (IR) responded fairly well with the conventional triple combined regimens and as good as sensitive cases with the intensive short course regimens $\mathrm{s}^{4,5}$.

In the meantime it has been suggested elsewhere that a continuous survey of drug resistance would provide useful epidemiological information for planning treatment programme and for monitoring efficacy and/or efficiency of chemotherapy of the national tuberculosis control programme $(\mathrm{NTP})^{2 \sim 5,7)}$.

In this regard we have investigated into drug resistance of $M$. tuberculosis isolates either from patients screened out of the sample population of the nationwide tuberculosis prevalence surveys that had been performed at the five year intervals since 1965 or from the routine laboratory cultures.

\section{MATERIALS AND METHODS}

\section{M. Tuberculosis Isolates}

\section{1) From the Surveys}

The nation-wide tuberculosis prevalence surveys (NTPS) had been carried out at the five years inteval since the first survey of 1965 . All the isolates of $M$. tuberculosis from patients screened out of the sample population were submitted to susceptibility tests against the various antituberculous drugs. The number of isolates tested were 71 in 1965, 132 in 1970, 270 in 1975, 177 in 1980, 247 in 1985, and 189 in 1990 survey.

2) From the Routine Laboratory Cultures

Clinical isolates from the newly diagnosed patients with pulmonary tuberculosis in the chest clinics of the Korean National Tuberculosis Association or in private or public hospitals were also sub mitted to drug susceptibility tests in our laboratory The number of isolates tested were 233 in 1962 3, 548 in 1964 5, 329 in 1966 7, 281 in 1968, 211 in 1970 $\sim 1,189$ in 1975, 1194 in 1977 8, 306 in 1980, 202 in $1982 \sim 3,563$ in $1984 \sim 5$, and 149 in 1986 7.

\section{Drug Susceptibility Tests}

The procedure of drug susceptibility tests was based on the absolute concentration method described by Cenetti et $a l^{8,9)}$ with a little modification of inoculum preparation and size ${ }^{10)}$. The tests were done in Löwenstein-Jensen Medium. The preinspis sation critical concentrations of the drugs by which probably resistant strains have been separated from sensitive strains were $0.2 \mu \mathrm{g} / \mathrm{ml}$ for isoniazid (INH), $32 \mu \mathrm{g} / \mathrm{ml}$ for rifampicin (RMP), $10 \mu \mathrm{g} / \mathrm{ml}$ for streptomycin (SM), $2.8 \mu \mathrm{g} / \mathrm{ml}$ for ethambutol (EMB), 100 $\mu \mathrm{g} / \mathrm{ml}$ for pyrazinamide (PZA), $1 \mu \mathrm{g} / \mathrm{ml}$ for $\rho$ aminosalicylic acid (PAS), $50 \mu \mathrm{g} / \mathrm{ml}$ for kanamycin (KM), $50 \mu \mathrm{g} / \mathrm{ml}$ for tuberactinomycin (TUM), $56 \mu \mathrm{g} /$ $\mathrm{ml}$ for prothionamide (PTH), and $40 \mu \mathrm{g} / \mathrm{ml}$ for cycloserine (CS). In 1965 and 1970 surveys the strains 
were tested against only SM, PAS, and INH but, in the subsequent surveys, all of aforementioned drugs were used to the tests.

\section{RESULTS}

Table 1 sets out prevalence of drug resistance in

Table 1. Drug Resistance of Mycobacterium Tuberculosis in the Nation-wide Tuberculosis prevalence Surveys

\begin{tabular}{|c|c|c|c|c|c|c|c|c|c|c|c|}
\hline \multirow{2}{*}{$\begin{array}{l}\text { Survey } \\
\text { year }\end{array}$} & \multirow[b]{2}{*}{ Patients } & \multirow{2}{*}{$\begin{array}{l}\text { Total } \\
\text { cases } \\
\text { studied }\end{array}$} & \multicolumn{9}{|c|}{ Resistance to } \\
\hline & & & $\begin{array}{c}\geq 1 \\
\text { drugs }\end{array}$ & $\begin{array}{c}\geq 3 \\
\text { drugs }\end{array}$ & $\mathrm{INH}+$ & RMP+ & $\mathrm{S} \mathrm{M}+$ & EMB + & $\begin{array}{c}\text { INH } \\
\text { RMP+ }\end{array}$ & $\begin{array}{l}\text { INH } \\
\text { SM+ }\end{array}$ & $\begin{array}{c}\text { INH } \\
\text { EMB+ }\end{array}$ \\
\hline \multirow[t]{6}{*}{1965} & New & 42 & 11 & & 7 & & 4 & & & 1 & \\
\hline & $\%$ & 100.0 & 26.2 & & 16.7 & & 9.5 & & & 2.4 & \\
\hline & Old & 29 & 16 & 1 & 11 & & 7 & & & 2 & \\
\hline & $\%$ & 100.0 & 55.2 & 3.4 & 37.9 & & 24.1 & & & 6.9 & \\
\hline & Both & 71 & 27 & 1 & 18 & & 11 & & & 3 & \\
\hline & $\%$ & 100.0 & 38.0 & 1.4 & 25.4 & & 15.5 & & & 4.2 & \\
\hline \multirow[t]{6}{*}{1970} & New & 92 & 22 & 6 & 18 & & 13 & & & 10 & \\
\hline & $\%$ & 100.0 & 23.9 & 6.5 & 19.6 & & 14.1 & & & 10.9 & \\
\hline & Old & 40 & 28 & 11 & 28 & & 12 & & & 12 & \\
\hline & $\%$ & 100.0 & 70.0 & 27.5 & 70.0 & & 30.0 & & & 30.0 & \\
\hline & Both & 132 & 50 & 17 & 46 & & 25 & & & 22 & \\
\hline & $\%$ & 100.0 & 37.9 & 12.9 & 34.8 & & 18.9 & & & 16.7 & \\
\hline \multirow[t]{6}{*}{1975} & New & 189 & 38 & 10 & 34 & 2 & 16 & 2 & 2 & 13 & 2 \\
\hline & $\%$ & 100.0 & 20.1 & 5.3 & 18.0 & 1.1 & 8.5 & 1.1 & 1.1 & 6.9 & 1.1 \\
\hline & Old & 81 & 60 & 20 & 59 & 2 & 28 & 2 & 1 & 27 & 2 \\
\hline & $\%$ & 100.0 & 74.1 & 24.7 & 72.8 & 2.5 & 34.6 & 2.5 & 1.2 & 33.3 & 2.5 \\
\hline & Both & 270 & 98 & 30 & 93 & 4 & 44 & 4 & 3 & 40 & 4 \\
\hline & $\%$ & 100.0 & 36.3 & 11.1 & 34.4 & 1.5 & 16.3 & 1.5 & 1.1 & 14.8 & 1.5 \\
\hline \multirow[t]{6}{*}{1980} & New & 108 & 33 & 6 & 27 & & 5 & 6 & & 3 & 4 \\
\hline & $\%$ & 100.0 & 30.6 & 5.6 & 25.0 & & 4.6 & 5.6 & & 2.8 & 3.7 \\
\hline & Old & 69 & 52 & 20 & 50 & 3 & 20 & 17 & 3 & 18 & 15 \\
\hline & $\%$ & 100.0 & 75.4 & 29.0 & 72.5 & 4.3 & 29.0 & 24.6 & 4.3 & 26.1 & 21.7 \\
\hline & Both & 177 & 85 & 26 & 77 & 3 & 25 & 23 & 3 & 21 & 19 \\
\hline & $\%$ & 100.0 & 48.0 & 14.7 & 43.5 & 1.7 & 14.1 & 13.0 & 1.7 & 11.9 & 10.7 \\
\hline \multirow[t]{6}{*}{1985} & New & 161 & 28 & 6 & 22 & 4 & 6 & 6 & 4 & 2 & 6 \\
\hline & $\%$ & 100.0 & 17.4 & 3.7 & 13.7 & 2.5 & 3.7 & 3.7 & 2.5 & 1.2 & 3.7 \\
\hline & Old & 86 & 48 & 14 & 41 & 22 & 8 & 14 & 17 & 6 & 13 \\
\hline & $\%$ & 100.0 & 55.8 & 16.3 & 47.7 & 25.6 & 9.3 & 16.3 & 19.8 & 7.0 & 15.1 \\
\hline & Both & 247 & 76 & 20 & 63 & 26 & 14 & 20 & 21 & 8 & 19 \\
\hline & $\%$ & 100.0 & 30.8 & 8.1 & 25.5 & 10.5 & 5.7 & 8.1 & 8.5 & 3.2 & 7.7 \\
\hline \multirow[t]{6}{*}{1990} & New & 127 & 19 & 6 & 16 & & 9 & 2 & & 7 & 2 \\
\hline & $\%$ & 100.0 & 15.0 & 4.7 & 12.6 & & 7.1 & 1.6 & & 5.5 & 1.6 \\
\hline & Old & 62 & 29 & 8 & 26 & 9 & 12 & 7 & 9 & 10 & 7 \\
\hline & $\%$ & 100.0 & 46.8 & 12.9 & 41.9 & 14.5 & 19.4 & 11.3 & 14.5 & 16.1 & 11.3 \\
\hline & Both & 189 & 48 & 14 & 42 & 9 & 21 & 9 & 9 & 17 & 9 \\
\hline & $\%$ & 100.0 & 25.3 & 7.4 & 22.2 & 4.8 & 11.1 & 4.8 & 4.8 & 9.0 & 4.8 \\
\hline
\end{tabular}


new and old patients screened from the sample populations of the last six nationwide tuberculosis prevalence surveys. Resistance to one or more antituberculous drugs was found in $38.0 \%$ of $M$. tuberculosis isolates from patients found in 1965 survey and the prevalence remained unchanged until it increased up to $48.0 \%$ in 1980 survey. Multiple drug resistance, namely resistance to three or more drugs, was also highest (14.7\%) in 1980 survey, suggesting that a considerable number of treatment failure cases might have been accumulated probably due to ineffective chemotherapy. However drug resistance decreased significantly in 1985 survey, showing $30.8 \%$, and further reduction was observed in 1990 survey, showing $25.3 \%$. It may indicate a reduced influx of treatmet failures into pool of bacillary cases prevalent.

In general it has been well known that resistance to individual drugs pararells with the extent of use of the relevant drug and with efficacy of the regimens including the corresponding drug. For example, INH resistance was found most frequently showing 25 . $4 \%$ in $1965,34.8 \%$ in $1970,34.4 \%$ in $1975,43.5 \%$ in $1980,25.5 \%$ in 1985 , and $22.2 \%$ in 1990 because this drug has been used most widely. A continuous decrease after 1980 indicates a significant improvement of efficacy of the regimens containing INH, mostly for initial treatment. The next common resistance was found to streptomycin as it increased up to $18.9 \%$ in 1970 and then decreased before it increased again in 1990. Less use of streptomycin due to a extreme rare incidence of the anaphylactic shock might have resulted in a continuous decrease of SM resistance after 1970. However increase in 1990 again could not be explained. On the contrary, RMP or EMB resistance was encountered most often in the recent surveys because wide use of these drugs started in late 1970s and early 1980s. However resistances to these drugs are in a decreasing trend in the last survey.

Drug resistance of smear positive cases, who are the major infectious sources in the community, sets out in Fig. 1. Estimated number of smear positive cases were approximately 166,000 in a total population of 28.6 million in $1965\left(580 / 10^{5}\right)$ and dropped to 54,000 in a total population of 42.8 million in 1990 $\left(126 / 10^{5}\right)$. The proportions of patients, who had past or current chemotherapy history, were $41.0 \%$ of

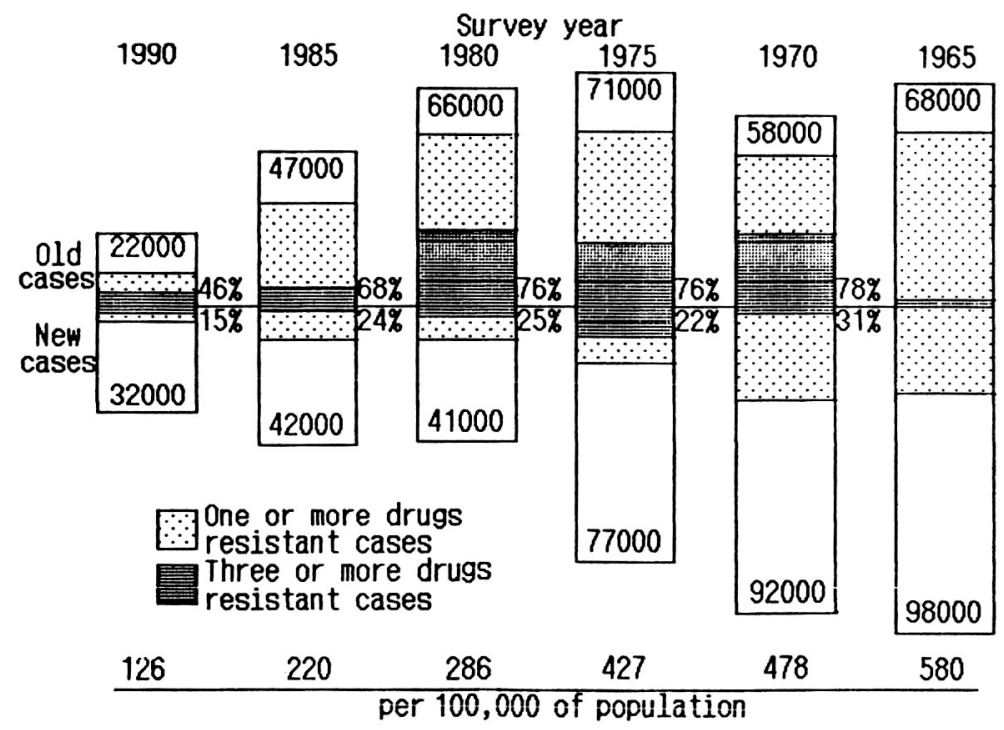

Fig. 1. Estimated smear positive cases with or without drug resistance. 
smear positive cases found in $1965,38.7 \%$ in 1970 , $48.0 \%$ in $1975,61.7 \%$ in $1980,52.8 \%$ in 1985 , and $40.6 \%$ in 1990 . From 1965 through 1985 , over twothirds $(67.8 \% \sim 77.8 \%)$ excreted organisms resistant to one or more antituberculous drugs. However it has decreased to $46.4 \%$ in 1990 survey. Including initial drug resistace (IR), $49.3 \%$ of smear positives found in 1970 were resistant to one or more drugs, $47.3 \%$ in $1975,57.6 \%$ in $1980,46.5 \%$ in 1985 , and $27.5 \%$ in 1990 .

Although a considerable number of smear positive cases prevalent in the country excreted drug resistant bacilli, IR did not increase continuously as seen in Table 1. IR was $26.2 \%$ in 1965 and increased up to $30.6 \%$ in 1980 but it decreased to a large extent in the subsequent surveys showing $17.4 \%$ in 1985 and $15.0 \%$ in 1990 .

Decrease of acquired resistance (AR) between 1980 and 1990 was also remarkable. A large decrease of AR (resistance of patients having past or current chemotherapy history) might have been resulted from (1) considerable reduction of treatment failures and (2) increased proportion of sensitive relapse cases among patients with a previous chemotherapy history. As seen in Fig. 2, drug resistance among patients having a history of more than 12 months treatment was $90.2 \%$ in $1980,71.7 \%$ in 1985 , and 56 . $5 \%$ in 1990 . Drug resistance of patients treated for three months or less was also much lower in the last survey when compared with those of the previous surveys.

It is a matter of concern to have observed significantly higher prevalence of IR among younger age group of patients, for intance an average prevalence in less than 30 years old patients was $31.8 \%$, while it was $14.1 \%$ in age group of 60 years or more as seen in Table 2. Whether the younger the more patients have been infected with drug resistant organisms is not known. There was also a significant difference in IR prevalence between urban and rural patients, showing much higher resistance among the former than the latter group. The main reason why IR is high among urban patients may be that urban patients could access to drugs more easily than rural patients. However there was no significant difference between male and female patients.

IR of clinical isolates from the routine cultures set out in Table 3. Although there are some fluctuation, drug resistance seems to have increased up to late 1970 s or early 1980 s, especially multiple drug resis-

\section{Survey year}

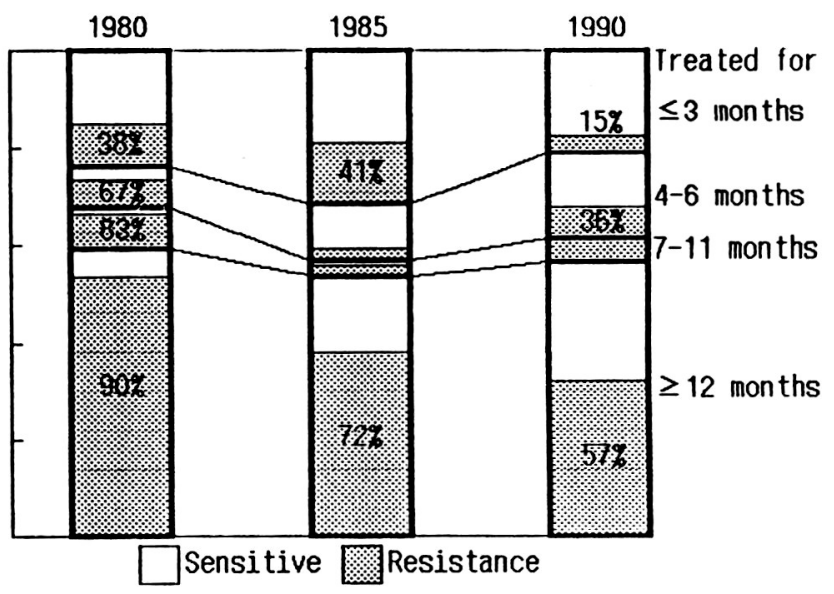

Fig. 2. Drug resistance (AR) of the patients with past or current chemotherapy history. 
Table 2. Initial Drug Resistance by Age, Sex, and Areas in the Nationwide Tuberculosis Prevalence Surveys

\begin{tabular}{|c|c|c|c|c|c|c|c|}
\hline & & \multicolumn{5}{|c|}{ Survey year } & \multirow[b]{2}{*}{ Total } \\
\hline & & 1970 & 1975 & 1980 & 1985 & 1990 & \\
\hline \multirow[t]{3}{*}{ Age } & $\leq 29$ & ${ }^{*} 10 / 22(45.5)$ & $12 / 53(22.6)$ & $8 / 21(38.1)$ & $15 / 45(33.3)$ & $4 / 13(30.8)$ & $49 / 154(31.8)$ \\
\hline & $30 \sim 59$ & $11 / 51(21.6)$ & $20 / 89(22.5)$ & $15 / 49(30.6)$ & $8 / 69(11.6)$ & $10 / \dot{6} 6(15.1)$ & $64 / 324(19.8)$ \\
\hline & $\geq 60$ & $2 / 19(10.5)$ & $6 / 47(12.8)$ & $10 / 38(26.3)$ & $5 / 47(10.6)$ & $5 / 48(10.4)$ & $28 / 199(14.1)$ \\
\hline \multirow[t]{2}{*}{ Area } & Urban & $18 / 49(36.7)$ & $21 / 68(30.9)$ & $22 / 49(44 .()$ & $22 / 82(26.8)$ & $13 / 70(18.6)$ & $96 / 318(30.2)$ \\
\hline & Rural & $5 / 43(11.6)$ & $17 / 121(14.0)$ & $11 / 59(18.6)$ & $6 / 79(7.6)$ & $6 / 57(10.5)$ & $45 / 359(12.5)$ \\
\hline \multirow[t]{2}{*}{ Sex } & Male & $15 / 67(22.4)$ & $24 / 121(19.8)$ & $16 / 61(26.2)$ & $21 / 116(18.1)$ & $13 / 92(14.1)$ & $89 / 457(19.5)$ \\
\hline & Female & $8 / 25(32.0)$ & $14 / 68(20.6)$ & $17 / 47(36.2)$ & $7 / 45(15.6)$ & $6 / 35(17.1)$ & $52 / 220(23.6)$ \\
\hline
\end{tabular}

※ Number of drug resistant cases/number of cases studied $\quad ※(\quad)=\%$

Table 3. Initial Drug Resistance of the Patients Diagnosed Under the Routine Services, 1962 to 1987

\begin{tabular}{|c|c|c|c|c|c|c|c|c|c|c|c|c|c|}
\hline \multirow{2}{*}{$\begin{array}{l}\text { Survey } \\
\text { year }\end{array}$} & \multirow{2}{*}{$\begin{array}{l}\text { No. of } \\
\text { cases } \\
\text { studied }\end{array}$} & \multicolumn{12}{|c|}{ Resistance prevalences $(\%)$ to } \\
\hline & & $\underset{\text { drug }}{\geq 1}$ & $\begin{array}{c}\geq 2 \\
\text { drugs }\end{array}$ & $\begin{array}{c}\geq 3 \\
\text { drugs }\end{array}$ & $\begin{array}{c}\geq 4 \\
\text { drugs }\end{array}$ & INH & RMP & $\mathrm{S} \mathrm{M}$ & EMB & PZA & $\begin{array}{l}\text { INH } \\
\text { RMP }\end{array}$ & $\begin{array}{l}\text { INH } \\
\text { S M }\end{array}$ & $\begin{array}{l}\text { INH } \\
\text { EMB }\end{array}$ \\
\hline $1962 \sim 3$ & 233 & 17.6 & 6.0 & & & 9.9 & & 8.2 & & & & 2.6 & \\
\hline $1964 \sim 5$ & 548 & 23.5 & 9.0 & 4.4 & & 17.2 & & 10.9 & & & & 6.0 & \\
\hline $1966 \sim 7$ & 329 & 27.7 & 14.3 & 4.6 & & 24.6 & & 12.2 & & & & 10.0 & \\
\hline 1968 & 281 & 24.6 & 10.3 & 5.0 & & 22.1 & & 10.0 & & & & 7.8 & \\
\hline $1970 \sim 1$ & 211 & 26.1 & 9.0 & 4.3 & & 22.3 & & 9.5 & & & & 7.1 & \\
\hline 1975 & 189 & 20.1 & 10.1 & 5.3 & 1.6 & 18.0 & & 8.5 & & & & 6.9 & \\
\hline $1977 \sim 8$ & 1194 & 31.7 & 13.3 & 7.1 & 3.4 & 28.6 & 1.0 & 3.7 & 5.4 & & 0.2 & 3.1 & 4.5 \\
\hline 1980 & 306 & 29.4 & 15.7 & 8.8 & 5.2 & 26.5 & 3.9 & 7.2 & 8.2 & 0.7 & 3.6 & 4.9 & 6.2 \\
\hline $1982 \sim 3$ & 202 & 26.7 & 15.8 & 7.9 & 5.4 & 23.3 & 5.9 & 5.9 & 7.9 & 1.0 & 5.4 & 5.9 & 7.9 \\
\hline $1984 \sim 5$ & 563 & 18.8 & 8.7 & 4.6 & 1.2 & 17.1 & 3.6 & 4.3 & 5.2 & 0.5 & 3.4 & 3.6 & 4.8 \\
\hline $1986 \sim 7$ & 148 & 20.8 & 7.3 & 3.3 & 1.3 & 18.1 & 4.0 & 5.4 & 2.0 & & 3.4 & 3.4 & 2.0 \\
\hline
\end{tabular}

tance, but it decreased afterward. Resistance to one or more drugs was found in $17.6 \%$ of the strains tested in $1962 \sim 3,31.7 \%$ in $1977 \sim 8,26.7 \%$ in 1982 $\sim 3$, and $20.8 \%$ in $1986 \sim 7$ and resistance to three or more drugs was $4.4 \%$ in $1964 \sim 5,7.1 \%$ in $1977 \sim 8$ and $3.3 \%$ in $1986 \sim 7$.

Because INH has been used as a basic drug in all the initial treatment regimens, resistance prevalence to this drug was fairly well coincided with that of all drug resistances alone or in combination. PAS and SM resistances continuously decreased after 1970 because they were used less and less. EMB resistance sharply increased in early 1980 because wide use of this drug started in late 1970 by replacing it with PAS in then standard regimen, SM/PAS/INH, for initial treatment in NTP. RMP resistance steadily increased after introduction of the short course regimen into NTP in early 1980.

\section{DISCUSSION}

From this study it was evident that the prevalence of drug resistance remained unchanged from $1060 \mathrm{~s}$ to 1970 s but it increased significantly in late 1970 and in early 1980. A continuous decrease, however, were followed thereafter. Such change might have closely 
related with case-finding activity and efficacy and efficiency of the current and past chemotherapy programme.

In early 1960 s initial treatment regimens that were used most widely were either PAS/INH, SM/INH or SM/PAS/INH. Full-fletched activity of NTP began in late 1960 s and three drug regimen such as $\mathrm{SM} / \mathrm{PAS} / \mathrm{INH}$ or SM/INH/EMB was available for all new patients found in the health centers in 1970 s. Efficacy (negative conversion rate of those who completed chemotherapy) of SM/INH/EMB under programme condition was found to be $66 \%$, and efficiency (negative conversion rate of those who have started chemotherapy) was $41 \%$ in 1981 assessment as seen in Table 4. Before 1980, efficiency of $\mathrm{SM} / \mathrm{INH} / \mathrm{EMB}$ or SM/PAS/INH should not be better than those observed in 1981 and 1982 assessments. Case-finding of tuberculosis patients in the health centers was extended considerably in 1970s without improvement of treatment efficiency. As a result, accumulation of drug resistant cases seemed to be unavoidable in late 1970 and so it might turned out to be a high prevalence of drug resistance in 1980 survey. However a remarkable improvement in both efficacy and efficiency could be achieved by introduction of the short course regimen, INH/RMP/ EMB, partly in 1982 and a subsequent nationwide extension in the following years. Efficacy of INH/ RMP/EMB was over $92 \%$ after 1982 and efficiency reached to $80 \%$ in 1988 as seen in Table 4 . The improved efficacy as such might have led to a significant reduction of drug resistance in the following surveys. Extension of treatment coverage with INH/ $\mathrm{RMP} / \mathrm{EMB}$ eventually led to a continuous increase of the over-all efficiency of NTP treatment programme from $60 \%$ in 1984 to $77 \%$ in 1989 . The prevalence rate of drug resistance showed an inverse relationship with the over-all efficiency of NTP treatment programme as seen in Fig. 3. In other word the higher the efficiency of chemotherapy programme underwent, the lower the prevalence of drug resistance was observed. Therefore, as suggested elsewhere $e^{2 \sim 5,7)}$, it is evident that a continuous survey on drug resistance may serve as a useful parameter in evaluation of the current or past chemotherapy programme and also provides useful information on the type that should be used for the treatment of the patients appearing in the health institutes for the first

Table 4. Efficacy and Efficiency of Initial Treatments and Retreatments in the Korean National Tuberculosis Programme

\begin{tabular}{|c|c|c|c|c|c|c|c|c|c|c|c|}
\hline \multirow{3}{*}{$\begin{array}{c}\text { Year } \\
\text { assessed }\end{array}$} & \multicolumn{6}{|c|}{ Initial treatments } & \multirow{2}{*}{\multicolumn{3}{|c|}{ Retreatments }} & \multirow{2}{*}{\multicolumn{2}{|c|}{ Over-all }} \\
\hline & \multicolumn{3}{|c|}{ INH/RMP/EMB } & \multicolumn{3}{|c|}{$\mathrm{SM} / \mathrm{INH} / \mathrm{EMB}$} & & & & & \\
\hline & No & $\mathrm{EFC}(\%)$ & $\mathrm{EFN}(\%)$ & No & $\operatorname{EFC}(\%)$ & $\mathrm{EFN}(\%)$ & No & $\mathrm{EFC}(\%)$ & $\mathrm{EFN}(\%)$ & $\mathrm{EFC}(\%)$ & $\operatorname{EFN}(\%)$ \\
\hline 1981 & & & & 571 & 66 & 41 & 493 & 74 & 47 & $<74$ & $<47$ \\
\hline 1982 & 174 & 87 & 73 & 923 & 60 & 41 & 1,043 & 71 & 48 & $<71$ & $<48$ \\
\hline 1983 & 380 & 92 & 75 & 292 & 75 & 52 & 492 & 74 & 52 & $<80$ & $<55$ \\
\hline 1984 & 4,694 & 92 & 75 & 5,085 & 75 & 52 & 3,619 & 74 & 52 & 81 & 60 \\
\hline 1985 & 8,922 & 94 & 75 & 6,763 & 80 & 56 & 6,472 & 78 & 56 & 85 & 64 \\
\hline 1986 & 14,774 & 94 & 77 & 3,256 & 79 & 57 & 3,541 & 80 & 56 & 90 & 71 \\
\hline 1987 & 15,045 & 95 & 79 & 2,745 & 82 & 58 & 3,025 & 80 & 59 & 91 & 73 \\
\hline 1988 & 15,559 & 95 & 80 & 2,212 & 84 & 58 & 2,744 & 81 & 58 & 92 & 75 \\
\hline 1989 & 15,882 & 96 & 81 & 2,113 & 86 & 55 & 2,133 & 85 & 61 & 94 & 77 \\
\hline
\end{tabular}

No=number of cases assessed. EFC=efficacy. EFN=efficiency. Data provided by the Department of Technical Cooperation of the Korean Institute of Tuberculosis 


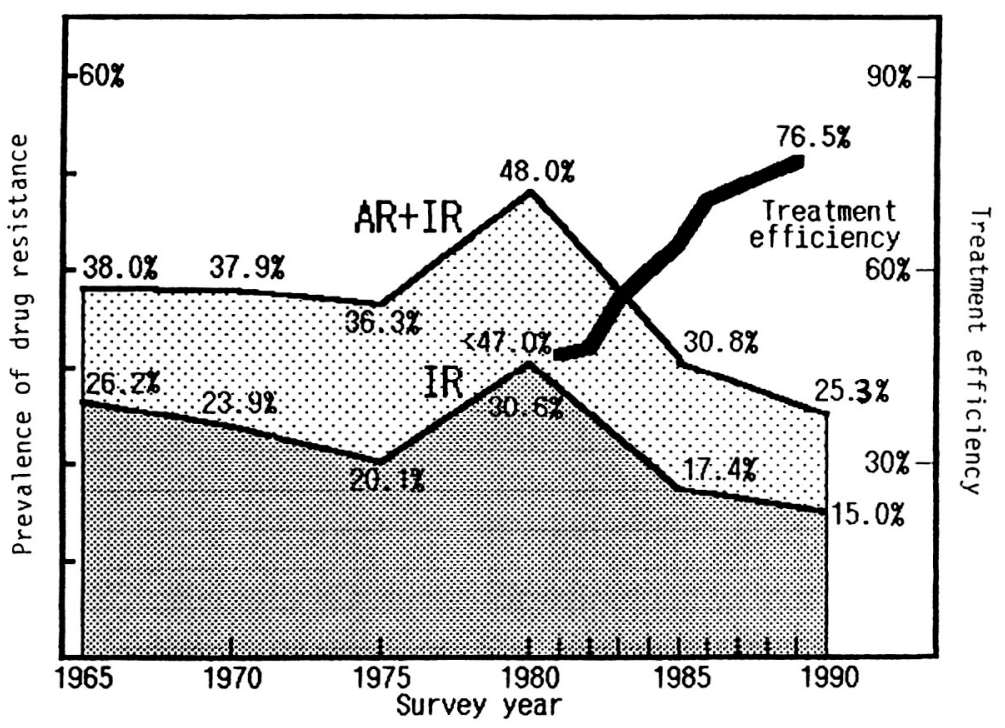

Fig. 3. Possible impact of treatment efficiency of NTP on the prevalence of drug resistance. $\mathrm{AR}=$ acquired drug resistances, $\mathrm{IR}=$ intial drug resistance

time.

\section{SUMMARY}

Drug resistance of $M$. tuberculosis has been investigated with isolates from patients screened out of the sample population of the nationwide tuberculosis prevalence surveys or from the routine cultures. The results showed a close inverse relationship between prevalence of drug resistance and efficiency of the past or current treatment regimens of NTP. Individual drug resistance also showed a close relationship with the extent of use of the relevant drugs. Drug resistance was found in $38.0 \%$ of $M$. tuberculosis isolates from patients found in 1965 survey and remained unchanged until it increased upto $48.0 \%$ in 1980 survey. The resistance prevalence, however, dropped to $30.8 \%$ in 1985 and further to $25.3 \%$ in 1990 survey. Such decrease was fairly well coincided with a continuous increase of the treatment efficiency (from 60\% in 1984 to $77 \%$ in 1989) in 1980 s.

Initial drug resistance also showed a similar trend, namely $26.2 \%$ in $1965,23.9 \%$ in $1970,20.1 \%$ in 1975 ,
$30.6 \%$ in $1980,17.4 \%$ in 1985 , and $15.0 \%$ in 1990 . The similar figures were observed in $M$. tuberculosis isolates from patients diagnosed in the routine services. Higher prevalence of initial drug resistance was observed among urban patients than rural patients and among young patients than old patients.

These findings signify that a continuous survey on drug resistance permits to monitor efficiency of treatment programme of the country.

\section{REFERENCES}

1) David HL: Drug-resistance in $M$. tuberculosis and other mycobacteria. Clin Chest Med 1:227, 1980

2) Gangadharam PRJ: Drug resistance in mycobacteria. CRC Press, Inc., Florida, USA, 1984

3) Mitchison DA: Primary drug resistance. Bull IUAT 32:81, 1962

4) Mitchison DA: Drug resistance in mycobacteria. Brit Med Bull 40:84, 1984

5) Kim SJ: The problem of initial drug resistance. Proc 1st Congr Asian Pacific Soc Respir, 1988, P 133

6) Kleeberg HH, Boshoff MS:World atlas of initial drug resistance. Tuberculosis Research institute of the South Africa 1984 
7) Canetti G: The eradication of tuberculosis: Theoretical problems and practical solutions. Tubercle 43: 301, 1962

8) Canetti G, Froman S, Grosset J, Hauduroy P, Langerova M, Mahler HJ, Meissner G, Mitchison DA, Sula L: Mycobacteria: laboratory methods for testing durg sensitivity and resistance. Bull WHO 29: 565,1963

9) Canetti G, Fox W, Khomenko A, Mahler HJ, Menon
NK, Mitchison DA, Rist N, Smelev NA: Advances in techniques of testing mycobacterial drug sensitivity and the use of sensitivity tests in tuberculosis control programs. Bull WHO 41:21, 1969

10) Kim SC: Primary drug resistance of Mycobacterium tuberculosis isolated from untreated patients with pulmonary tuberculosis in Korea. Kekkaku (Japan) 46(5):165, 1971 